\title{
Vascular pathology in the aged human brain
}

\author{
Lea Tenenholz Grinberg • Dietmar Rudolf Thal
}

Received: 24 June 2009/Revised: 3 February 2010/Accepted: 4 February 2010/Published online: 14 February 2010

(C) The Author(s) 2010. This article is published with open access at Springerlink.com

\begin{abstract}
Cerebral atherosclerosis (AS), small vessel disease (SVD), and cerebral amyloid angiopathy (CAA) are the most prevalent arterial disorders in the aged brain. Pathogenetically, AS and SVD share similar mechanisms: plasma protein leakage into the vessel wall, accumulation of lipid-containing macrophages, and fibrosis of the vessel wall. CAA, on the other hand, is characterized by the deposition of the amyloid $\beta$-protein in the vessel wall. Despite these differences between CAA, AS and SVD, apolipoprotein $\mathrm{E}$ (apoE) is involved in all three disorders. Such a pathogenetic link may explain the correlations between AS, SVD, CAA, and Alzheimer's disease in the brains of elderly individuals reported in the literature. In addition, AS, SVD, and CAA can lead to tissue lesions such as hemorrhage and infarction. Moreover, intracerebral SVD leads to plasma protein leakage into the damaged vessel wall and into the perivascular space resulting in a blood-brain barrier (BBB) dysfunction. This SVD-related BBB dysfunction is considered to cause white matter
\end{abstract}

L. T. Grinberg and D. R. Thal contributed equally and are listed in alphabetic order.

\section{T. Grinberg}

Department of Neurology, University of California

San Francisco, 305 Parnassus Avenue,

San Francisco, CA 94143, USA

\section{T. Grinberg}

Aging Brain Research Group, Department of Pathology, University of Sao Paulo Medical School, Av. Dr. Arnaldo, 455 sala 1353, São Paulo, SP 01246903, Brazil

\section{R. Thal $(\square)$}

Laboratory of Neuropathology, Center for Clinical Research, Institute of Pathology, University of Ulm,

Helmholtzstrasse 8/1, 89081 Ulm, Germany

e-mail: Dietmar.Thal@uni-ulm.de lesions (WMLs) and lacunar infarcts. In this review, we demonstrate the relationship between AS, SVD, and CAA as well as their contribution to the development of vascular tissue lesions and we emphasize an important role for apoE in the pathogenesis of vessel disorders and vascular tissue lesions as well as for BBB dysfunction on WML and lacunar infarct development.

Keywords Atherosclerosis - Small vessel disease . Cerebral amyloid angiopathy $\cdot$ Brain infarction . Hemorrhages - White matter lesions

\section{Introduction}

The three most important vessel disorders in the elderly brain are cerebral atherosclerosis (AS), small vessel disease (SVD), and cerebral amyloid angiopathy (CAA). All three disorders can lead to infarction and hemorrhage [56, 87, 102]. SVD is also associated with white matter lesions (WMLs) [48]. Infarction, hemorrhage, and WMLs cause the destruction of brain tissue and, thereby, frequently cause neurological symptoms.

This review is aimed at identifying pathogenetic mechanisms involved in AS, SVD, and CAA that may explain their correlation with one another and with vascular lesions, such as hemorrhage, infarction, and WMLs. To address this aim, we will first summarize the current knowledge about these vessel disorders. Second, we will discuss the correlation between these vessel diseases and the proteins involved in the pathogenesis of all three disorders. Third, we will summarize the current concepts about the involvement of apolipoprotein $\mathrm{E}$ (apoE) in these vessel disorders, and discuss potential pathogenetic mechanisms that may represent a link among them. Then, 
the relationship between the vessel disorders and vascular brain lesions will be reported and pathogenetic mechanisms will be discussed.

\section{Pathology of major vessel disorders in the aging brain}

\section{Atherosclerosis}

Atherosclerosis is a degenerative vessel disorder that frequently affects large- to medium-sized arteries. In the brain, the vessels of the circle of Willis are often involved $[5,66]$. The occurrence and the severity of AS in the circle of Willis increase with age (Table 1). AS changes in small arteries overlap with those found in SVD. Atherosclerotic plaques are prone to rupture with subsequent thrombosis $[119,120]$. The thrombus resulting from plaque rupture can either lead to vessel occlusion or it can embolize and occlude a smaller artery [73]. Embolism is most frequently originated from the extracerebral parts of the vertebral artery and the common and internal carotid arteries [73]. Atherosclerotic aneurysm is a consequence of cerebral vessel wall destruction, rarely leading to subsequent rupture and hemorrhage [56].

Intima thickening and accumulation of blood-derived lipids in the intima initiate the development of AS [66, 121]. Further intima proliferation, splitting of the lamina elastica interna and the accumulation of cholesterol-laden macrophages lead to the generation of atherosclerotic plaques [119-121] (Fig. 1a, b), which is accompanied by further destruction of the vessel wall and the accumulation of T-lymphocytes and macrophages [42, 119-121]. In later stages, AS plaques exhibit a necrotic core, cholesterol clefts and calcifications [119]. AS plaque rupture is associated with (1) inflammation, including the secretion of cytokines [e.g. interleukin (IL)-1 $\alpha$, IL-12, IL-18], (2) collagen-degrading enzymes, such as matrix-metalloproteinases (e.g. MMP-1, MMP-9) and the neutrophil elastase, which are involved in the degradation of the vessel wall [20, 21, 23, 71, 72], (3) anti-oxidative stress response as indicated by the presence of glutathione-S-transferase omega [65], and (4) endothelial/ intimal alteration as indicated by the occurrence of plasma proteins [e.g. $\alpha 2$-macroglobulin (A2M; Fig. 1), neutrophil elastase] in the AS plaque [70, 117]. Arterial hypertension is a well-known risk factor for AS [76] and may foster plasma protein leakage into the vessel wall. Other risk factors are increased homocysteine plasma levels found in AS patients [148] and the 677C-T mutation in the MTHFR gene (methylenetetrahydrofolate reductase-an enzyme that is involved in the remethylation of homocysteine, the mutation results in increased plasma homocysteine levels) [32].

ApoE and its receptors are critically involved in the pathogenesis of AS. ApoE-knockout mice and low-density lipoprotein (LDL) receptor knockout mice develop AS [8, 156]. Dysfunctional uptake of LDLs may, thereby, lead to the accumulation of oxidized LDLs in the atherosclerotic vessel wall [9]. Thus, oxidized LDLs may be candidates to trigger the development of atherosclerotic plaques. ApoE and LDL receptors [e.g. LDLR and A2M receptor/LDL receptor-related protein $(\mathrm{LRP}=\mathrm{CD} 91)]$ were found in AS plaques (Fig. 1c) [8, 43]. The apoE $\varepsilon 4$ allele is controversially discussed as a possible genetic risk factor for AS [64, 75, 116]. The second ligand of LRP, the plasma protein A2M, also accumulates within AS plaques (Fig. 1d) [117] and an association of its deletion/insertion polymorphism with the expansion of AS plaques within the circle of Willis has been reported [70]. The accumulation of A2M within the AS plaque did not correlate with the type of the AS lesions [71] suggesting that plasma protein influx including A2M may play a role in the initiation of $\mathrm{AS}$ plaques but not for plaque rupture. In summary, apoE, LDL receptors and A2M are involved in the pathogenesis of AS. Leakage of plasma apoE and A2M possibly contributes to the development of AS plaques.

Table 1 Distribution of frequencies of autopsy cases with a given extent of atherosclerosis (AS) within the arteries of the circle of Willis (CaW) among different age groups

\begin{tabular}{llcr}
\hline Extent of AS & \multicolumn{2}{l}{ Frequency of cases/\% in the age group } \\
\cline { 2 - 4 } & $60-70$ years & $71-80$ years & 81 years and older \\
\hline No AS & 20.69 & 3.57 & 4.00 \\
$1-25 \%$ of CaW vessels with AS & 17.24 & 7.14 & 12.00 \\
$26-50 \%$ of CaW vessels with AS & 20.69 & 32.14 & 8.00 \\
$51-75 \%$ of CaW vessels with AS & 24.14 & 35.71 & 40.00 \\
$76-100 \%$ of CaW vessels with AS & 17.24 & 21.43 & 36.00 \\
\hline
\end{tabular}

The table presents the percentage of cases without AS and with AS in a given extent in the age groups 60-70, 71-80, and 81 years and older. This observation is based on the data obtained from 82 non-selected autopsy cases. The circle of Willis was observed macroscopically for the presence or absence of the 11 arteries of the circle of Willis as previously described [70]. The extent of AS was calculated as: number of AS-affected vessels $\times 100 /$ number of investigated vessels of the circle of Willis [70]. The cases analyzed here were already included in other studies under other aspects $[65,70]$ 
Fig. 1 a, b The left internal carotid artery of a 79-year-old man exhibits severe

atherosclerotic changes (Type 5 according to Stary [119]). There is a thinning of the lamina media, proliferation and lipid accumulation in the intima including cholesterol clefts (arrows). The necrotic core is covered by a fibromuscular tissue layer (arrowheads) indicative for Stary Type 5 lesions. b Corresponds to a high magnification view of the boxed area in (a). ApoE (c) and A2M (d) occur in the plaque core of an AS plaque. Staining in $(\mathbf{a}, \mathbf{b})$ Elastica van Gieson (EVG), c anti-apoE [Covance (Dedham, USA), D6E10, 1/500, formic acid and microwave pretreatment], $\mathbf{d}$ anti-A2M [BioMac (Germany, Leipzig), polyclonal rabbit, 1/5,000]. The calibration bar in (b) corresponds to: a $400 \mu \mathrm{m}$, b $90 \mu \mathrm{m}, \mathbf{c}, \mathbf{d} 70 \mu \mathrm{m}$

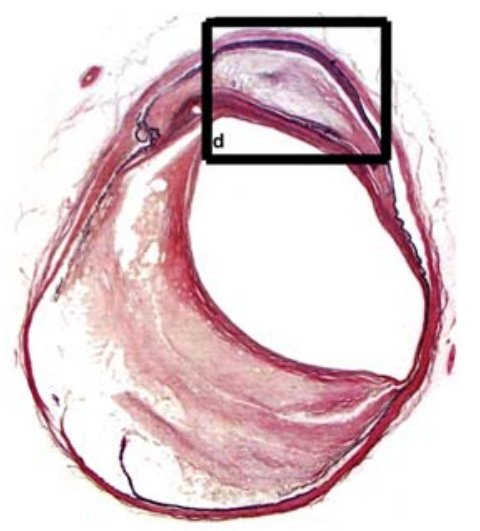

(a)

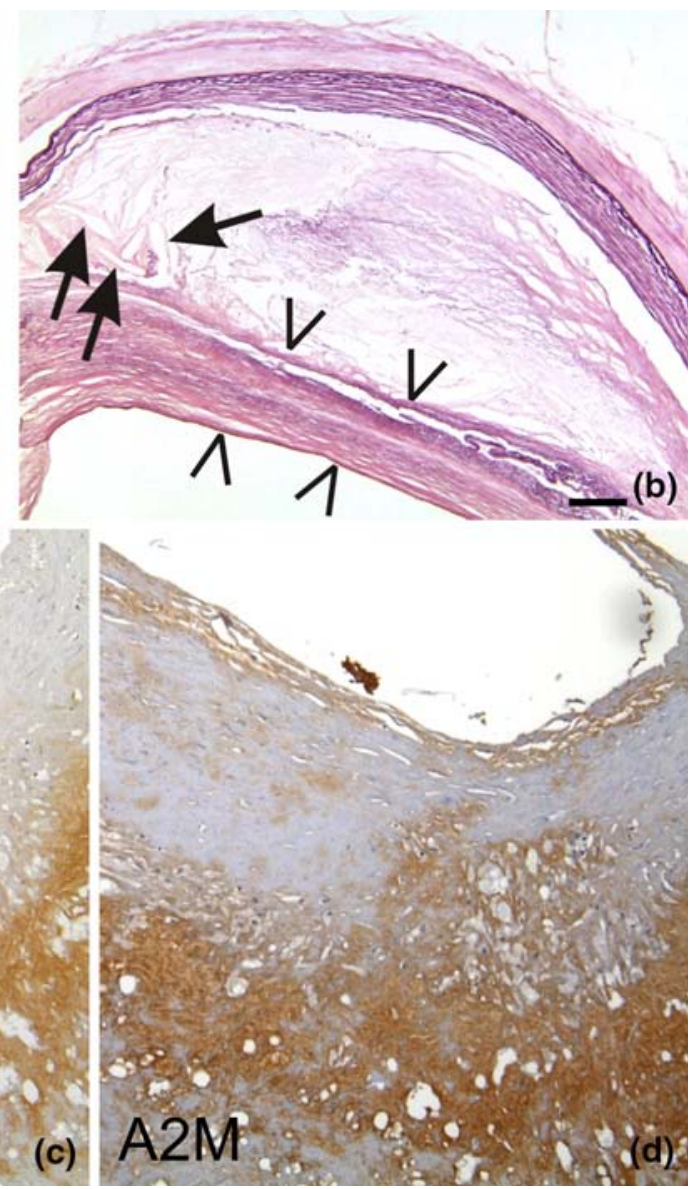

\section{Small vessel disease}

Small vessel disease encompasses degenerative alterations in the vessel wall of the small arteries and arterioles that are assumed to be pathogenetically linked [51, 67, 142]. SVD includes changes also described as small vessel arteriosclerosis/atherosclerosis, arteriolosclerosis, and lipohyalinosis [51, 67, 142]. These three subforms of SVD and how they are pathogenetically linked to one another will be discussed hereunder. CAA is not included in this group basically because of differences in the pathogenesis and the location of affected vessels.

Small vessel arteriosclerosis/atherosclerosis constitutes AS in small intracerebral and leptomeningeal arteries (200-800 $\mu \mathrm{m}$ in diameter). The vessels show endothelial proliferation, splitting of the lamina elastica interna (Fig. 2a), small plaque-like accumulations of plasma proteins, lymphocytes and macrophages (microatheroma) [31, 67]. The pathogenesis is similar to that of AS including the role of apoE leakage and the mechanisms responsible for thrombosis and hemorrhage development [67]. Smaller arteries (40-300 $\mu \mathrm{m})$ exhibit asymmetric areas of fibrosis/ hyalinosis associated with foam cells and leakage of plasma proteins such as apoE, A2M, and immunoglobulin
$\mathrm{G}$ (IgG) (Fig. 2b-f) termed lipohyalinosis. The initial lesion is a fibrinoid necrosis of the vessel wall in the absence of inflammation [67]. High arterial pressure and blood-brain barrier (BBB) breakdown are implicated in plasma protein leakage and fibrinoid necrosis in this disease $[68,91,92]$. Lipohyalinosis is different from concentric hyaline thickening of small arteries $(40-150 \mu \mathrm{m}$ in diameter) leading to a concentric stenosis of the vessel lumen (Fig. 2g) [67] termed arteriolosclerosis. Due to the high blood pressure, plasma proteins, such as albumin, $\mathrm{A} 2 \mathrm{M}$ and apoE, leak into the vessel wall and into the perivascular brain parenchyma $[1,139]$ (Fig. $2 \mathrm{~h}-\mathrm{i}$ ). These changes are usually seen in white matter arteries [84, 140, 151].

SVD is first seen in the arteries of the basal ganglia, mainly in the putamen and the globus pallidus, which exhibit small vessel AS and lipohyalinosis. Secondly, small white matter arteries become affected by arteriolosclerosis or lipohyalinosis. Leptomeningeal arteries of the hemispheres and the cerebellum develop small vessel AS in parallel. Brain stem arteries, including those located between the pontine nuclei, usually develop lipohyalinosis or arteriolosclerosis only in the end stage of SVD [129]. Cortical vessels are usually free of SVD [129]. Enlarged 

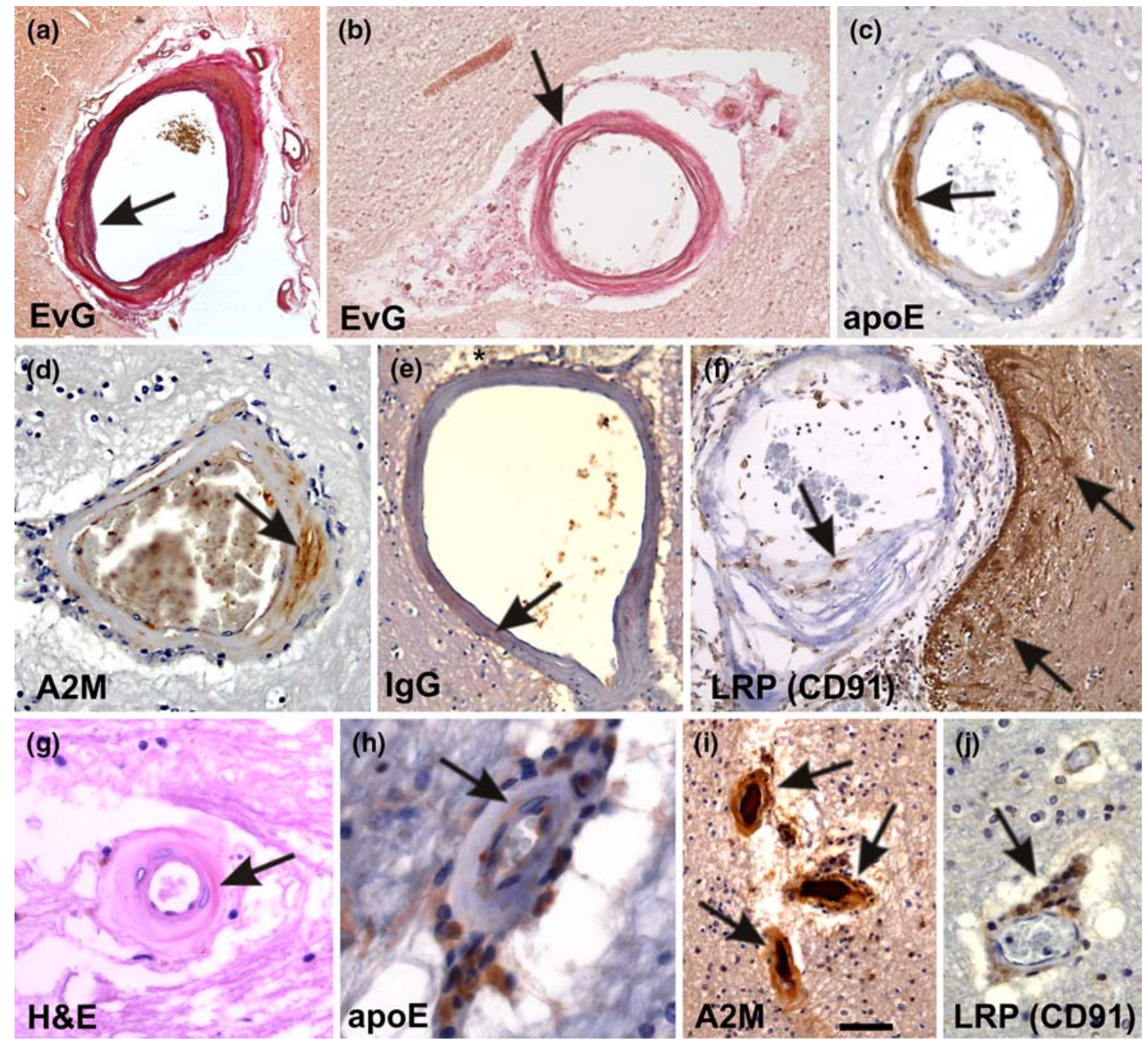

Fig. 2 Small vessel disease-related changes. a A leptomeningeal artery shows intima proliferation and a splitting of the internal elastic lamina (arrow). These changes are related to small vessel arteriosclerosis/atherosclerosis. b A white matter artery exhibits fibrosis, lipohyalinosis of the vessel wall, and fibrinoid necrosis (arrow). Lipohyalinosis affected vessels exhibit the plasma proteins apoE (c), A2M (d), and $\operatorname{IgG}(\mathbf{e})$ within the vessel wall (arrows in $\mathbf{c}-\mathbf{e}$ ) indicating the leakage of plasma proteins into the vessel wall and into the perivascular space (asterisk in e). f Macrophages within the lipohyalinotic lesions and perivascular astrocytes strongly exhibit the A2M and apoE receptor LRP (CD91) (arrows) indicating that these cells are capable of taking up A2M and apoE. g Arteriolosclerosis of a white matter artery shows severe hyalinization (arrow) of the vessel wall. $\mathbf{h}-\mathbf{j}$ ApoE and A2M were observed within the vessel wall of arteriolosclerotic vessels (arrows in $\mathbf{h}, \mathbf{i}$ ). Within the enlarged perivascular spaces

perivascular spaces are often associated with SVD-affected vessels. As such, all subforms of SVD contribute to this hierarchical expansion of SVD changes throughout the brain and seem to be pathogenetically linked.

Arterial hypertension and diabetes mellitus are risk factors for SVD [69]. However, this association is lacking in a significant number of cases [69]. Plasma protein leakage into the vessel wall including apoE and $\mathrm{A} 2 \mathrm{M}$ is a high numbers of apoE (h), A2M (i), and LRP-positive cells (arrow in $\mathbf{j}$ ) were observed indicating that these perivascular cells accumulate apoE and $\mathrm{A} 2 \mathrm{M}$ due to an insufficient perivascular drainage. These perivascular macrophages are often Prussian blue negative and do not necessarily represent hemorrhagic residues [129]. Stainings in $\mathbf{a}-\mathbf{j}$ as indicated. Anti-apoE and anti-A2M staining was performed as indicated in Fig. 1. For anti-IgG and anti-LRP immunohistochemistry the following antibodies were used [anti-IgG: polyclonal goat; Biomeda, Foster City, CA; 1/100; microwave pretreatment; anti-LRP (antiCD91): $\alpha 2-\mathrm{M}-\mathrm{R}-\mathrm{II} 2 \mathrm{C} 7$; BioMac, Leipzig, Germany; 1/150; microwave and protease pretreatment]. The calibration bar in $\mathbf{i}$ corresponds to: a $300 \mu \mathrm{m}, \mathbf{b} 80 \mu \mathrm{m}, \mathbf{c} 40 \mu \mathrm{m}, \mathbf{d}, \mathbf{j} 35 \mu \mathrm{m}, \mathbf{e}, \mathbf{f} 60 \mu \mathrm{m}, \mathbf{g} 20 \mu \mathrm{m}, \mathbf{h} 16 \mu \mathrm{m}$, i $50 \mu \mathrm{m}$. $\mathbf{a}$ and $\mathbf{b}$ are reproduced from Thal et al. 2003 [129] with kind permission

common feature in all three subforms of SVD (Fig. 2c-e, $h, j)$. Genetically, an association between SVD and the apoE $\varepsilon 4$ allele has been reported [154].

Cerebral amyloid angiopathy

Deposits of amyloid $\beta$-protein $(A \beta)$ in the cerebral and leptomeningeal vessel walls are characteristic of CAA in 
both sporadic and $A \beta$-related familiar forms [34, 55, 108]. $\mathrm{A} \beta$ deposits occur in arteries, veins and capillaries [141] (Fig. 3a, b). $A \beta_{40}$ is more predominant in vascular $A \beta$ deposits than in parenchymal ones $[45,110]$. In the sporadic form of CAA, vascular A $\beta$ deposition is strongly associated with AD-related pathology and around 80$100 \%$ of all AD patients have CAA $[3,4,51,55,108$, $126,129,132,141]$. Morphologically, two types of CAA can be distinguished: CAA with capillary involvement (CAA-type 1) and CAA lacking capillary $\mathrm{A} \beta$ deposition (CAA-type 2) [130]. Capillary CAA is more common in $\mathrm{AD}$ patients $[4,132]$ and it can induce capillary occlusions resulting in disturbances of cerebral blood flow [128]. The severity of CAA is related to the degree of vessel wall destruction [144]. Intracerebral hemorrhage, cerebral infarction [14, 79, 132, 141], and CAA-related angiitis $[62,78,107]$ are complications of CAA (Fig. 3c).

CAA begins in cortical and leptomeningeal vessels of neocortical areas and then, expands into vessels of allocortical areas and the cerebellum. In single cases, even white matter arteries and vessels of the basal ganglia, the diencephalon, and/or the brain stem exhibit CAA [129, 132]. This hierarchical pattern resembles the one described for $\mathrm{A} \beta$ plaques $[2,131,134]$.

Physiologically, brain-derived $A \beta$ is drained along the perivascular space $[15,147]$ and the vascular basement membranes $[16,146]$. Alterations of this clearance pathway may result in the deposition of $A \beta$ near the basement membrane [146]. In addition, smooth muscle cell-derived $A \beta$ is potentially capable of contributing to the deposition of $A \beta$ in the vessel wall $[85,86]$. ApoE plays an important role in the pathogenesis of CAA. It is found in vascular $A \beta$ deposits [93] and it is physiologically drained along the perivascular space co-occurring with $A \beta[133,139]$. ApoE binds $A \beta$ [123]. Alterations of the perivascular drainage of $\mathrm{A} \beta$ and apoE likely lead to CAA [133, 146, 147]. CAA, especially capillary CAA, is associated with the apoE $\varepsilon 4$ allele [37, 100, 103, 126, 130, 132]. This finding points to an important role of apoE for the development of CAA because apoE4 is less effective in the receptor-mediated clearance of $A \beta$ when compared to apoE3 [19]. This property of apoE4 presumably results in capillary $A \beta$ deposition in apoE $\varepsilon 4$ carriers as soon as alterations in the perivascular drainage occur. In addition, the apoE $\varepsilon 4$ genotype promotes $A \beta$ aggregation in vascular smooth muscle cell cultures [85]. Finally, CAA-related hemorrhage is reported to be associated with the apoE $\varepsilon 2$ and $\varepsilon 4$ allele [37, 88, 95, 97].

In familial cases, other amyloidogenic proteins can also aggregate in the cerebral blood vessels and cause other forms of CAA, i.e., ABri, ADan, transthyrretin, gelsolin, cystatin $\mathrm{D}$, and prion protein [108]. Unlike $\mathrm{A} \beta$-related

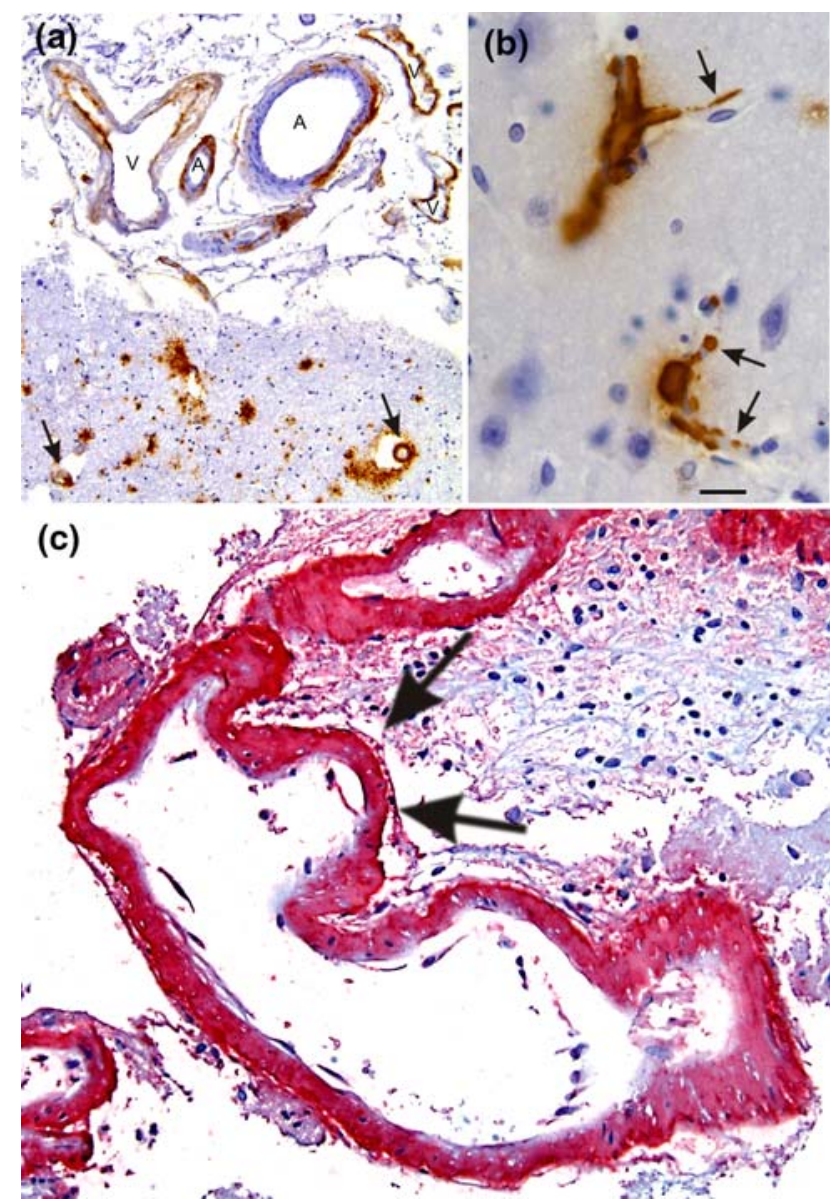

Fig. 3 Cerebral amyloid angiopathy (CAA). a A $\beta$ deposition in the vessel wall of leptomeningeal arteries $(A)$ and veins $(V)$ as well as in cortical arteries (arrows). b Capillary CAA is characterized by A $\beta$ deposits at the basement membrane of cortical capillaries (arrows). c Severe CAA in a case of CAA-related hemorrhage. The CAAaffected artery exhibits multiple aneurysmal dilations of the vessel wall as indicated by arrows. A $\beta$ deposits are stained in red (permanent red; DAKO, Glostrup, Denmark) with an antibody against $A \beta_{17-24}$ (4G8, Covance, Dedham, USA, 1/5,000, pretreatment with formic acid). The same antibody was also used in figures a and $\mathbf{b}$ but 3,3-diaminobencidine- $\mathrm{HCl}$ was used as chromogen. The calibration bar in b corresponds to: a $85 \mu \mathrm{m}, \mathbf{b}, \mathbf{c} 20 \mu \mathrm{m}$

CAA, these forms of CAA are usually not restricted to the cerebral and leptomeningeal vessels [108].

\section{Relationship between SVD subforms, AS, and CAA}

Although AS, SVD, and CAA are distinct disease entities, they correlate with one another as well as with $\mathrm{AD}$ except for AS, which did not correlate with CAA [5, 13, 109, 129]. In our own sample, we confirmed the correlation between AS and SVD, SVD and CAA, SVD and AD, and CAA and $\mathrm{AD}$ whereas there was no significant correlation between AS and CAA, and AS and AD (Table 2). In the 
Table 2 Correlations between extent of cerebral atherosclerosis (AS), small vessel disease (SVD), cerebral amyloid angiopathy (CAA), and Alzheimer's disease (AD)

\begin{tabular}{lclr}
\hline Correlation between & $r$ & $p$ & $n$ \\
\hline AS-SVD & 0.475 & 0.003 & 36 \\
AS-CAA & -0.109 & 0.488 & 43 \\
AS-AD & 0.15 & 0.175 & 83 \\
SVD-CAA & 0.252 & 0.025 & 79 \\
SVD-AD & 0.177 & 0.022 & 166 \\
CAA-AD & 0.575 & 0.001 & 87 \\
\hline
\end{tabular}

The extent of AS was obtained as described in the legend of Table 1. The extent of SVD and CAA was measured by the stage of SVD and CAA distribution throughout the entire brain [129]. AD was diagnosed in the event that the pathology of the demented cases showed a moderate or high likelihood for AD according to the NIA-Reagan criteria [135]. Non-AD controls were all cases that did not match the NIA-Reagan criteria and did not develop dementia

$r$ Spearman rho correlation coefficient, $p$ probability, $n$ number of cases analyzed

light of these correlations, it is tempting to speculate that AS, SVD, and CAA share common or linked pathogenetic mechanisms.

SVD and AS exhibit similar morphological alterations. For example, atherosclerotic lesions in small arteries are defined either as AS or as SVD (subform: small vessel arteriosclerosis/atherosclerosis). Partly, this overlap is explained by the similarities of the pathogenetic mechanism of AS in large- and medium-sized vessels as well as in small vessels [67], such as plasma protein leakage into the vessel wall. On the other hand, there are morphological differences that justify the distinction between AS and the SVD subform small vessel arteriosclerosis/atherosclerosis: AS plaques in large- and medium-sized vessels often contain cholesterol clefts and calcifications, which are usually not seen in small vessel arteriosclerosis/atherosclerosis.

SVD itself is subclassified into small vessel arteriosclerosis/atherosclerosis, arteriolosclerosis, and lipohyalinosis/ fibrinoid necrosis. Despite morphological differences, plasma protein leakage into the vessel wall and/or into the perivascular space are common features of all three subforms (Figs. 2, 4a). The hierarchical expansion of SVD, encompassing all of its subforms, throughout the brain, as described in detail in "Small vessel disease", also argues in favor of a common disease entity with different presentations in larger and smaller vessels rather than three different vessel disorders.

A pathogenetic link between AS and SVD on the one hand and CAA on the other is less obvious. However, apoE occurs in the SVD- and AS-related vessel wall lesions and in association with CAA-related $\mathrm{A} \beta$ deposits. Moreover, the apoE $\varepsilon 4$ allele is a risk factor for CAA [100, 115, 126],
SVD [154], and is discussed as a risk factor for AS [64, 75, 116]. The absence of apoE in apoE-knockout mice results in AS and hypercholesterolemia [156]. These points indicate that apoE is a common player in the pathogenesis of all three vessel disorder and may represent a pathogenetic link.

\section{The role of apoE in vessel pathology of the aging brain}

Apolipoprotein E appears to be a common player in the pathogenesis of AS, SVD, and CAA. It is a plasma protein produced by hepatocytes and macrophages [77] and it functions as a transporter for cholesterol and other lipids [77]. In the brain, apoE is produced by astrocytes [10, 77]. Under physiological conditions, an intact BBB prevents the influx of plasma apoE into the brain [22, 27]. Brain-apoE is drained along perivascular channels and vascular basement membranes [133]. It can bind cholesterol, lipids, and proteins such as $A \beta[77,123]$, which are cleared together with apoE $[6,106]$, suggesting that apoE may have a transporter function not only for cholesterol and lipids but also for proteins such as $\mathrm{A} \beta$.

In AS- and SVD-affected vessels, plasma proteins including apoE leak into the vessel wall and accumulate in the respective lesion $[1,18,91,92,139,150]$ (Figs. 1, 2, 4). Plasma proteins also leak into the perivascular space of vessels affected by SVD indicating an alteration of the precapillary segment of the BBB [127, 139]. Thus, SVD presumably impairs perivascular clearance, including that of $A \beta$ and apoE, by several mechanisms: (1) SVD-induced fibrosis of the vessel wall may decrease the capacity for drainage along the basement membranes [146], (2) the increasing stiffness of the SVD-affected arteries leads to a less effective outward transport of the perivascular fluid due to a cessation of the pulsations [146, 147], and (3) the SVD-induced leakage of plasma proteins including apoE into the vessel wall and the perivascular space competes for perivascular drainage with the extracellular fluid of the brain [127, 136, 137, 139] (Fig. 4). Therefore, SVD presumably contributes to the accumulation of $A \beta$ in the brain leading to CAA and Alzheimer's disease-related $A \beta$ plaque deposition. This hypothesis is supported by the association between SVD, CAA, and A $\beta$ plaque deposition $[13,129]$ (Table 2) and by the increase of plasma $A \beta_{1-40}$ in patients with SVD [35]. Since SVD and CAA are both localized in intracerebral small arteries and arterioles, which have a perivascular space, and since both disorders develop apoEcontaining lesions $[93,139]$ and are associated with the apoE $\varepsilon 4$ allele as a genetic risk factor, it is tempting to assume that apoE represents a pathogenetic link between SVD and CAA. The hypothesis that apoE contributes to vessel wall destruction is further supported by the 


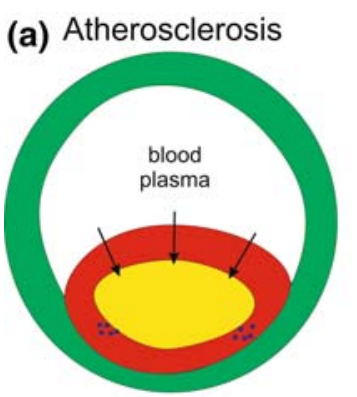

Lipohyalinosis

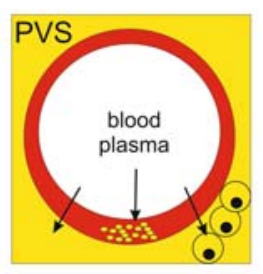

Arterioloscleosis

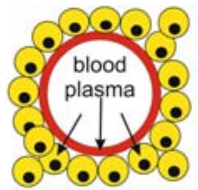

CAA

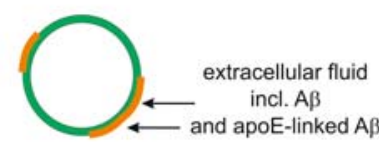

(b)

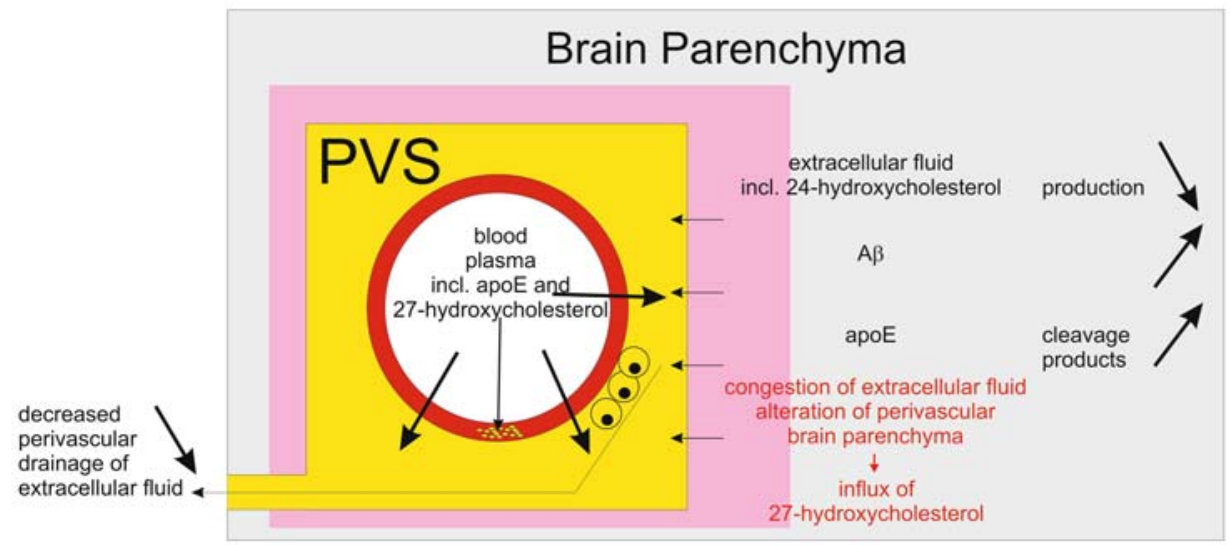

Fig. 4 Plasma protein leakage induced by vessel disorders and its relation to perivascular alterations of the brain parenchyma. a This schematic representation shows that plasma proteins occur (1) in the plaque cores of AS plaques, (2) in the vessel wall of lipohyalinotic vessels as well as in the perivascular space and in macrophages within the perivascular space, and (3) in the vessel wall of arteriolosclerotic vessels as well as in accompanying macrophages. CAA, on the other hand, is characterized by the deposition of proteins of the extracellular fluid of the brain, i.e. $A \beta$ [15] and apoE [133]. b Impact of plasma protein leakage into the brain. Physiologically, extracellular fluid is drained into the perivascular space and along the vascular

association of the apoE $\varepsilon 2$ and $\varepsilon 4$ alleles with CAA-related hemorrhages [37, 88, 95, 97].

One argument against the hypothesis that SVD-related BBB alterations contribute to the development of CAA and parenchymal $A \beta$ deposition is the lacking increase of apoE in the brain [139]. However, in the event that $A \beta$ accumulates in the brain, e.g. in $\mathrm{AD}$ cases, apoE clearance switches from perivascular drainage to enzymatic cleavage as indicated by the predominance of C-terminal truncated apoE over full-length apoE [139]. Hence, the absence of an apoE increase in the brain of $\mathrm{AD}$ patients or of patients with perivascular drainage deficits does not argue against the hypothesis that altered perivascular drainage of extracellular fluid leads to a congestion of extracellular fluid and proteins in the brain. Moreover, the increase of 27hydroxycholesterol levels in AD brains indicates an influx of plasma steroids through the BBB [46]. Another argument against a pathogenetic link between SVD and $A \beta$ accumulation in the brain is that $\mathrm{AD}$-related $\mathrm{A} \beta$ deposition basement membranes [16, 60, 155]. In the event of SVD, there is plasma protein leakage into the vessel wall and into the perivascular space [139] resulting in (1) a competition between leaking plasma and extracellular fluid from the brain for perivascular drainage and (2) the congestion of extracellular fluid leading to the accumulation and/or alternative processing of proteins of the extracellular fluid, and 3) the influx of the peripheral cholesterol metabolite 27-hydroxycholesterol into the brain $[46,127,139]$. The influx of 27 -hydroxycholesterol into the brain is accompanied by decreased levels of brain derived 24hydroxycholesterol indicating a reduction in the cerebral 24-hydroxycholesterol production [46]

in aged individuals first occurs in the cortex [11, 104, 129, 134] whereas SVD affects mainly white matter, leptomeningeal and basal ganglia vessels [129]. However, the cortex is a distal area in relation to the areas with SVDaffected vessels, and $A \beta$ is mainly produced by neurons located in this distal area [40, 94]. Thus, a proximal clearance block for peripheral extracellular fluid drainage containing neuron-derived $A \beta$ will lead to a protein accumulation, e.g. of $A \beta$, in distal areas such as the cortex. This is exactly where parenchymal and vascular $A \beta$ deposits occur first [11, 104, 129, 134]. Therefore, it is tempting to speculate that the distribution of $A \beta$ deposits in aging and $\mathrm{AD}$ brains may represent the result of insufficient clearance of $A \beta$, rather than an anterograde neuronal expansion as previously discussed [134]. A strong argument in favor of this hypothesis is the fact that normal brain transplants into APP-transgenic mice, which produce a high number of $A \beta$ plaques, also develop $A \beta$ plaques in the absence of neuronal connections [89]. 
Thus, SVD-related alterations of the BBB may contribute to the development of CAA and possibly of parenchymal $\mathrm{A} \beta$ deposition. In general, the results reviewed here for the fate of $\mathrm{A} \beta$ and apoE after SVDrelated $\mathrm{BBB}$ alteration point to two different effects of protein retention in the brain (1) accumulation, as documented for $\mathrm{A} \beta$, and (2) degradation as presumed for apoE. Therefore, it is likely to posit that accumulation or degradation of other proteins also takes place and may be related with other SVD-associated brain lesions.

\section{Vascular brain lesions and their relationship to AS, SVD, and CAA}

Brain infarction, hemorrhage, and WMLs are the major brain lesions related to AS, SVD, and CAA. The location and size of the lesions vary according to the underlying vessel disorders and the potential risk factors. Here, we will briefly describe the vascular brain lesions and their association with AS, SVD, and CAA.

\section{Brain infarction}

Brain infarction is a circumscribed brain tissue necrosis resulting from insufficient blood supply [73, 102]. Infarcts are subdivided by nature into ischemic (anemic) or hemorrhagic infarcts. Alternatively, the descriptive classification distinguishes large infarcts (those involving the supply territories of major cerebral arteries and veins), lacunar infarcts (i.e. small vessel infarcts), and microinfarcts.

First, we will describe the relationship between ischemic and hemorrhagic infarcts to AS, SVD, and CAA regardless of the size of the infarct. Ischemic infarcts occur when focal brain perfusion falls below critical levels and no relevant collateral or remaining blood flow is available. This type of infarct is seen after thrombosis of large- to medium-sized arteries with atherosclerotic plaque rupture with or without subsequent embolism or after occlusion of SVD- or CAA-affected vessels [14, 73, 141]. Cardiac embolism also causes ischemic brain infarction [29, 33, 73]. Hemorrhagic infarcts are characterized by blood influx into the infarct territory. Different mechanisms can be responsible for hemorrhagic infarcts: (1) embolism due to AS or cardiac thrombosis [29, 81] with insufficient blood influx into the infarcted tissue (the mechanism is not clear, partial lysis of the embolus with resting blood flow, which is insufficient to save the tissue, is considered), (2) reperfusion of an anemic infarct (e.g. following lysis therapy or resuscitation), (3) collateral blood influx (insufficient to save the tissue but enough to bleed), (4) infarction in areas in which the remaining vessels are fragile due to a vessel disease such as SVD or CAA [41], and (5) venous obstruction with subsequent congestion and extravasation of blood into the infarct area. Thus, AS, SVD, and CAA are related to infarcts, regardless of their nature. The underlying vessel disorder is, therefore, not predictive of the ischemic (anemic) or hemorrhagic nature of an infarct.

On the other hand, the underlying vessel disorders have influence on the infarct size. Large infarcts are bigger than $15-20 \mathrm{~mm}^{3}$. They are frequently ischemic (70-80\%) and due to thrombotic or embolic artery occlusion [73]. AS plaque rupture with subsequent thrombosis and/or embolism usually occurs in the extracranial parts of the vertebral and the internal and common carotid arteries [73, 81]. Large infarcts due cardiac embolism are less frequent [73, 81]. About $10 \%$ of all large infarcts are watershed infarcts. It is a distinct type of infarct located between two vessel territories that results from insufficient blood supply during hypotensive episodes [52, 57, 157]. SVD and CAA usually do not lead to large infarcts [73]. Therefore, large infarcts are mainly linked to AS and its complications. Lacunar infarcts are cavitating infarcts, measuring up to $5-15 \mathrm{~mm}^{3}$ in volume or $5-10 \mathrm{~mm}$ in diameter $[30,44,73,102]$. They are largely confined to the cerebral white matter and subcortical structures, most commonly found in the putamen, caudate nucleus, thalamus, pons, internal capsule and the cerebral white matter. Lacunar infarcts are associated with SVD [17, 74] but not with CAA. Pathogenetically, hypertension, diabetes, previous brain infarcts, an increase of high-density lipoproteins and triglycerides in the blood [36] were considered risk factors, but a recent review reported that this risk is not greater than that for large infarcts [49]. However, SVDaffected vessels showing lipohyalinosis or small vessel atherosclerosis are often found in the center of lacunar infarcts [30, 31, 111] presumably indicating that SVD is a major cause of lacunar infarcts. The risk factors described for lacunar infarcts are similar with those of AS and SVD. ASrelated or cardiac embolism can also cause lacunar infarcts [33]. As opposed to large and lacunar infarcts, microinfarcts are usually not visible at gross examination. They are smaller than $5 \mathrm{~mm}$ in diameter. Multiple microinfarcts in the cortex and the white matter rather than a single one likely impact cognition [48]. Microinfarcts result either from AS-related embolism, SVD, or CAA [14, 33, 53, 61, 99]. Due to the location of the underlying vessel disorder, cortical microinfarcts are often associated with CAA whereas subcortical infarcts are mainly linked to SVD [7, 14, 53, 99, 118, 129, 132, 143].

In summary, AS is capable of causing infarcts of all size, whereas SVD is only related to lacunar infarcts and microinfarcts and CAA is mainly restricted to microinfarcts. These relationships can be easily explained by the vessel types affected by the respective vessel disorders and do not seem to reflect a more specific pathomechanism. 
Hemorrhages

Cerebral hemorrhages are blood extravasations into the brain parenchyma larger than $10 \mathrm{~mm}$ in diameter and are differentiated from microbleeds. Together with other disorders, such as saccular aneurysms of the circle of Willis, vascular malformations, or coagulation disorders, AS, SVD, and CAA can lead to hemorrhage. In particular, AS results in hemorrhage after rupture of an atherosclerotic aneurysm [56], although this is a rare cause of intracerebral hemorrhage. More often, SVD leads to intracerebral hemorrhage, especially when it is associated with arterial hypertension. These hemorrhages preferentially occur after rupture of the lenticulostriate artery [125, 153]. Lobar hemorrhages with destruction of cortical tissue are frequently associated with severe CAA [50, 79, 141, 143]. Microaneurysms can be formed in SVD- and CAA-affected vessels (Fig. 3c) and are prone to rupture [87, 141, 142]. Microbleeds are blood extravasations into the perivascular and/or Virchow-Robin space without further tissue displacement and/or small intracerebral hemorrhages. They usually measure less than $10 \mathrm{~mm}$ in diameter [44] and are found in $\sim 6 \%$ of the population with an increasing tendency during aging, especially in the presence of CAA [38, 63, 138]. Hemosiderin-laden macrophages within the perivascular space indicate prior microbleeds [149]. Hypertension-related microbleeds are preferentially located in the basal ganglia, thalamus, and the pons in association with SVD-affected vessels [54]. Thus, SVD and CAA are the major causes of cerebral hemorrhage and microbleeds in the aged human brain, whereas AS complications rarely lead to cerebral bleedings.

\section{White matter lesions}

White matter lesions, synonymous with leukoaraioses when found in imaging examinations, are present in up to $65 \%$ of the subjects over 65 years of age. They are more prevalent in patients with cerebrovascular disease or with cardiovascular risk $[58,96]$. Clinically, WMLs are often asymptomatic [12, 25], but they can also impair cognition [26, 105]. Leukoencephalopathy, Binswanger's disease (synonymous with subcortical arteriosclerotic encephalopathy), periventricular arteriosclerotic leukoencephalopathy, and leukomalacia are clinical correlatives of WMLs [26, 48, 138]. Risk factors for the development of WMLs are advanced age, female sex [114], increased plasma homocysteine [47], increased ICAM levels [80], and arterial hypertension [24]. Some of these risk factors such as hypertension and increased plasma homocysteine levels also act as risk factors for AS and SVD. WMLs usually display, in variable degrees, white matter rarefaction (i.e., demyelination and axon loss), mild reactive astrocytosis, edema, and macrophage reaction [28, 39, 48, 124]. These changes are frequently observed in the frontal, parietal, temporal, and occipital deep white matter, especially in the centrum semiovale, and as a rule, spare the subcortical U-fibers, which are located close to the border between the cortex and the white matter $[59,98,101,113]$. It is not clear whether periventricular WMLs have the same nature as those in the deep white matter [28]. White matter infarcts, hemorrhages and enlarged perivascular spaces do not fall into the category of WMLs [48]. SVD-affected vessels are often seen together with perivascular WMLs [140]. AS and CAA, on the other hand, are not directly associated with WMLs because these vessel diseases are usually not seen in white matter vessels. Pathogenetically, SVD-related chronic hypoperfusion of the white matter and BBB alterations are presumed to lead to the degeneration of axons and myelin sheets, i.e. to WMLs [59, 98, 101, 136, 137, 140].

\section{Pathogenetic relations between vessel disorders and brain lesions}

According to the issues discussed above, SVD can lead to infarction, hemorrhage, and WMLs. In turn, infarction and hemorrhage can be caused by AS, SVD, and CAA. Thus, the type of brain lesion cannot be related to a specific vessel disorder and vice versa. All vessel disorders result in narrowing of the lumen of the affected blood vessels and can lead to vessel occlusion with subsequent infarction. Likewise, AS, SVD, and CAA damage the vessel wall. Rupture with subsequent hemorrhage can take place.

In addition to these non-specific mechanisms, WMLs and lacunar infarcts are mainly related to SVD. Despite vessel occlusion leading to lacunar infarcts, chronic hypoxia and SVD-related congestion of extracellular fluid may contribute to the development of WMLs and lacunar infarcts. This hypothesis is supported, first, by studies showing that chronic hypoxia presumably causes WMLs and lacunar infarcts given that oligodendrocytes are the most vulnerable cell type under these conditions and that their degeneration contributes to the development of WMLs and lacunar infarcts [48, 82, 83, 101, 122, 152]. Thereby, chronic hypoxia may result from SVD-related concentric fibrosis of the arterial walls and consecutive hypoperfusion [30, 31, 111, 112, 140]. Second, SVD leads to a leakage of plasma proteins, such as $\mathrm{IgG}, \mathrm{A} 2 \mathrm{M}$ and apoE, into the enlarged perivascular spaces [139]. Recently, BBB alterations in patients with leukoaraiosis (i.e. WMLs) and lacunar stroke have been described [136, 145]. Accordingly, these observations point to a SVDrelated alteration of the pre-capillary $\mathrm{BBB}$ segment involved in the pathogenesis of WMLs and lacunar infarcts 
and, thereby, extend the present knowledge of SVD-related $\mathrm{BBB}$ alterations and its association with vascular lesions in addition to AD-related changes [127, 139]. Moreover, it is well-known that plasma proteins leak into the brain parenchyma of hypertensive or hypotensive animals [91, 137] and patients with vascular dementia [1]. Endothelial changes have been found in animal models for hypo- as well as hypertension [91, 92, 137] indicating that endothelial cell alterations due to high arterial pressure or due to chronic hypoxia in hypotensive states are capable of promoting alterations of the pre-capillary BBB segment. In the light of all these considerations, it is tempting to speculate that chronic plasma protein leakage into the brain and retention of extracellular fluid due to altered perivascular clearance for the above-mentioned reasons contributes to the development of WMLs and/or lacunar infarcts (Fig. 4b) in addition to chronic hypoxia. Such a mechanism causing alterations of tissue is well-known in liver and lung congestion. Here, chronic hypoxia and a decreased venous drainage of extracellular fluid and blood lead to a perivenous parenchymal necrosis with subsequent fibrosis [90].

In short, hemorrhage and infarction result from nonspecific vessel wall changes seen in AS, SVD, and CAA whereas WMLs and lacunar infarcts appear to be specifically linked to SVD-related BBB leakage and chronic hypoxia.

\section{Conclusions}

Despite the etiology of the vessel disorders, infarction and hemorrhage appear to result non-specifically from vessel wall changes of the respective vessel disorders. WMLs and lacunar infarcts can be addressed quite specifically to SVD [140]. The alteration of the pre-capillary segment of the $\mathrm{BBB}$, thereby, allows leakage of plasma proteins into the vessel wall and into the perivascular space. These plasma proteins may compete with the extracellular fluid of the brain for perivascular drainage leading to retention of extracellular fluid, including $A \beta$ in the brain. Such a retention of $\mathrm{A} \beta$ may also contribute to the development of CAA and Alzheimer's disease. ApoE is physiologically involved in the perivascular clearance of the extracellular fluid from brain. It is found in AS, SVD, and CAA lesions, and may represent a link between these disorders. Taken together, SVD-related alterations of the pre-capillary segment of the BBB seem to play an important role in vascular pathology, i.e. WMLs, lacunar infarcts, and CAA.

Acknowledgments The results reviewed here were in part results from studies supported by DFG-Grant No. TH624/4-1, FAPESP No. 06/53818-1 and CAPES/DAAD PROBRAL No. 289/08. The authors thank Prof. Helmut Heinsen (University of Würzburg) and Dr. Kelly Del Tredici (University of Ulm) for critical reading of the manuscript.
LTG was supported by a scholarship of the Alexander von Humboldt Foundation.

Open Access This article is distributed under the terms of the Creative Commons Attribution Noncommercial License which permits any noncommercial use, distribution, and reproduction in any medium, provided the original author(s) and source are credited.

\section{References}

1. Alafuzoff I, Adolfsson R, Grundke-Iqbal I, Winblad B (1985) Perivascular deposits of serum proteins in cerebral cortex in vascular dementia. Acta Neuropathol 66:292-298

2. Alafuzoff I, Thal DR, Arzberger T, Bogdanovic N, Al-Sarraj S, Bodi I, Boluda S, Bugiani O, Duyckaerts C, Gelpi E, Gentleman S, Giaccone G, Graeber M, Hortobagyi T, Hoftberger R, Ince P, Ironside JW, Kavantzas N, King A, Korkolopoulou P, Kovacs GG, Meyronet D, Monoranu C, Nilsson T, Parchi P, Patsouris E, Pikkarainen M, Revesz T, Rozemuller A, Seilhean D, SchulzSchaeffer W, Streichenberger N, Wharton SB, Kretzschmar H (2009) Assessment of beta-amyloid deposits in human brain: a study of the BrainNet Europe Consortium. Acta Neuropathol 117:309-320

3. Attems J (2005) Sporadic cerebral amyloid angiopathy: pathology, clinical implications, and possible pathomechanisms. Acta Neuropathol 110:345-359

4. Attems J, Jellinger KA (2004) Only cerebral capillary amyloid angiopathy correlates with Alzheimer pathology - a pilot study. Acta Neuropathol (Berl) 107:83-90

5. Beach TG, Wilson JR, Sue LI, Newell A, Poston M, Cisneros R, Pandya Y, Esh C, Connor DJ, Sabbagh M, Walker DG, Roher AE (2007) Circle of Willis atherosclerosis: association with Alzheimer's disease, neuritic plaques and neurofibrillary tangles. Acta Neuropathol 113:13-21

6. Bell RD, Zlokovic BV (2009) Neurovascular mechanisms and blood-brain barrier disorder in Alzheimer's disease. Acta Neuropathol 118:103-113

7. Bergeron C, Ranalli PJ, Miceli PN (1987) Amyloid angiopathy in Alzheimer's disease. Can J Neurol Sci 14:564-569

8. Boucher P, Gotthardt M, Li WP, Anderson RG, Herz J (2003) LRP: role in vascular wall integrity and protection from atherosclerosis. Science 300:329-332

9. Boyd HC, Gown AM, Wolfbauer G, Chait A (1989) Direct evidence for a protein recognized by a monoclonal antibody against oxidatively modified LDL in atherosclerotic lesions from a Watanabe heritable hyperlipidemic rabbit. Am J Pathol 135:815-825

10. Boyles JK, Pitas RE, Wilson E, Mahley RW, Taylor JM (1985) Apolipoprotein E associated with astrocytic glia of the central nervous system and with nonmyelinating glia of the peripheral nervous system. J Clin Invest 76:1501-1513

11. Braak H, Braak E (1991) Neuropathological stageing of Alzheimer-related changes. Acta Neuropathol 82:239-259

12. Briley DP, Haroon S, Sergent SM, Thomas S (2000) Does leukoaraiosis predict morbidity and mortality? Neurology 54:90-94

13. Brun A, Englund E (1986) A white matter disorder in dementia of the Alzheimer type: a pathoanatomical study. Ann Neurol 19:253-262

14. Cadavid D, Mena H, Koeller K, Frommelt RA (2000) Cerebral beta amyloid angiopathy is a risk factor for cerebral ischemic infarction. A case control study in human brain biopsies. J Neuropathol Exp Neurol 59:768-773 
15. Calhoun ME, Burgermeister P, Phinney AL, Stalder M, Tolnay M, Wiederhold KH, Abramowski D, Sturchler-Pierrat C, Sommer B, Staufenbiel M, Jucker M (1999) Neuronal overexpression of mutant amyloid precursor protein results in prominent deposition of cerebrovascular amyloid. Proc Natl Acad Sci USA 96:14088-14093

16. Carare RO, Bernardes-Silva M, Newman TA, Page AM, Nicoll JA, Perry VH, Weller RO (2008) Solutes, but not cells, drain from the brain parenchyma along basement membranes of capillaries and arteries: significance for cerebral amyloid angiopathy and neuroimmunology. Neuropathol Appl Neurobiol 34:131-144

17. Challa VR, Bell MA, Moody DM (1990) A combined hematoxylin-eosin, alkaline phosphatase and high-resolution microradiographic study of lacunes. Clin Neuropathol 9:196-204

18. Chuang PT, Cheng HJ, Lin SJ, Jan KM, Lee MM, Chien S (1990) Macromolecular transport across arterial and venous endothelium in rats. Studies with Evans blue-albumin and horseradish peroxidase. Arteriosclerosis 10:188-197

19. Deane R, Sagare A, Hamm K, Parisi M, Lane S, Finn MB, Holtzman DM, Zlokovic BV (2008) apoE isoform-specific disruption of amyloid beta peptide clearance from mouse brain. J Clin Invest 118:4002-4013

20. Deguchi JO, Aikawa E, Libby P, Vachon JR, Inada M, Krane SM, Whittaker P, Aikawa M (2005) Matrix metalloproteinase13/collagenase- 3 deletion promotes collagen accumulation and organization in mouse atherosclerotic plaques. Circulation 112:2708-2715

21. Deguchi JO, Aikawa M, Tung CH, Aikawa E, Kim DE, Ntziachristos V, Weissleder R, Libby P (2006) Inflammation in atherosclerosis: visualizing matrix metalloproteinase action in macrophages in vivo. Circulation 114:55-62

22. Dietschy JM, Turley SD (2001) Cholesterol metabolism in the brain. Curr Opin Lipidol 12:105-112

23. Dollery CM, Owen CA, Sukhova GK, Krettek A, Shapiro SD, Libby P (2003) Neutrophil elastase in human atherosclerotic plaques: production by macrophages. Circulation 107:2829-2836

24. Dufouil C, de Kersaint-Gilly A, Besancon V, Levy C, Auffray E, Brunnereau L, Alperovitch A, Tzourio C (2001) Longitudinal study of blood pressure and white matter hyperintensities: the EVA MRI Cohort. Neurology 56:921-926

25. Englund E (1998) Neuropathology of white matter changes in Alzheimer's disease and vascular dementia. Dement Geriatr Cogn Disord 9(Suppl 1):6-12

26. Enzinger C, Fazekas F, Ropele S, Schmidt R (2007) Progression of cerebral white matter lesions-clinical and radiological considerations. J Neurol Sci 257:5-10

27. Fan J, Donkin J, Wellington C (2009) Greasing the wheels of Abeta clearance in Alzheimer's disease: the role of lipids and apolipoprotein E. Biofactors 35:239-248

28. Fazekas F, Kleinert R, Offenbacher H, Schmidt R, Kleinert G, Payer F, Radner H, Lechner H (1993) Pathologic correlates of incidental MRI white matter signal hyperintensities. Neurology 43:1683-1689

29. Fazio C (1949) Red softening of the brain. J Neuropathol Exp Neurol 8:43-60

30. Fisher CM (1965) Lacunes: small, deep cerebral infarcts. Neurology 15:774-784

31. Fisher CM (1991) Lacunar infarcts-a review. Cerebrovasc Dis $1: 311-320$

32. Frosst P, Blom HJ, Milos R, Goyette P, Sheppard CA, Matthews RG, Boers GJ, den Heijer M, Kluijtmans LA, van den Heuvel LP et al (1995) A candidate genetic risk factor for vascular disease: a common mutation in methylenetetrahydrofolate reductase. Nat Genet 10:111-113
33. Gerraty RP, Parsons MW, Barber PA, Darby DG, Desmond PM, Tress BM, Davis SM (2002) Examining the lacunar hypothesis with diffusion and perfusion magnetic resonance imaging. Stroke 33:2019-2024

34. Glenner GG, Wong CW (1984) Alzheimer's disease: initial report of the purification and characterization of a novel cerebrovascular amyloid protein. Biochem Biophys Res Commun 120:885-890

35. Gomis M, Sobrino T, Ois A, Millan M, Rodriguez-Campello A, Perez de la Ossa N, Rodriguez-Gonzalez R, Jimenez-Conde J, Cuadrado-Godia E, Roquer J, Davalos A (2009) Plasma betaamyloid 1-40 is associated with the diffuse small vessel disease subtype. Stroke 40:3197-3201

36. Gouw AA, van der Flier WM, Fazekas F, van Straaten EC, Pantoni L, Poggesi A, Inzitari D, Erkinjuntti T, Wahlund LO, Waldemar G, Schmidt R, Scheltens P, Barkhof F (2008) Progression of white matter hyperintensities and incidence of new lacunes over a 3-year period: the Leukoaraiosis and Disability study. Stroke 39:1414-1420

37. Greenberg SM, Briggs ME, Hyman BT, Kokoris GJ, Takis C, Kanter DS, Kase CS, Pessin MS (1996) Apolipoprotein E epsilon 4 is associated with the presence and earlier onset of hemorrhage in cerebral amyloid angiopathy. Stroke 27:1333-1337

38. Greenberg SM, Vernooij MW, Cordonnier C, Viswanathan A, Al-Shahi Salman R, Warach S, Launer LJ, Van Buchem MA, Breteler MM (2009) Cerebral microbleeds: a guide to detection and interpretation. Lancet Neurol 8:165-174

39. Grinberg LT, Amaro Junior E, da Silva AV, da Silva RE, Sato JR, dos Santos DD, de Paula Pacheco S, de Lucena Ferretti RE, Paraizo Leite RE, Pasqualucci CA, Teipel SJ, Flatz WH, Heinsen H (2009) Improved detection of incipient vascular changes by a biotechnological platform combining post mortem MRI in situ with neuropathology. J Neurol Sci 283:2-8

40. Haass C, Koo EH, Mellon A, Hung AY, Selkoe DJ (1992) Targeting of cell-surface beta-amyloid precursor protein to lysosomes: alternative processing into amyloid-bearing fragments. Nature 357:500-503

41. Hacke W, Schwab S, Horn M, Spranger M, De Georgia M, von Kummer R (1996) 'Malignant' middle cerebral artery territory infarction: clinical course and prognostic signs. Arch Neurol 53:309-315

42. Hansson GK, Jonasson L, Seifert PS, Stemme S (1989) Immune mechanisms in atherosclerosis. Arteriosclerosis 9:567-578

43. Heeren J, Beisiegel U, Grewal T (2006) Apolipoprotein E recycling: implications for dyslipidemia and atherosclerosis. Arterioscler Thromb Vasc Biol 26:442-448

44. Henry-Feugeas MC (2007) MRI of the 'Alzheimer syndrome'. J Neuroradiol 34:220-227

45. Herzig MC, Winkler DT, Burgermeister P, Pfeifer M, Kohler E, Schmidt SD, Danner S, Abramowski D, Sturchler-Pierrat C, Burki K, van Duinen SG, Maat-Schieman ML, Staufenbiel M, Mathews PM, Jucker M (2004) Abeta is targeted to the vasculature in a mouse model of hereditary cerebral hemorrhage with amyloidosis. Nat Neurosci 7:954-960

46. Heverin M, Bogdanovic N, Lutjohann D, Bayer T, Pikuleva I, Bretillon L, Diczfalusy U, Winblad B, Bjorkhem I (2004) Changes in the levels of cerebral and extracerebral sterols in the brain of patients with Alzheimer's disease. J Lipid Res 45:186-193

47. Hogervorst E, Ribeiro HM, Molyneux A, Budge M, Smith AD (2002) Plasma homocysteine levels, cerebrovascular risk factors, and cerebral white matter changes (leukoaraiosis) in patients with Alzheimer disease. Arch Neurol 59:787-793

48. Ince PG (2005) Acquired forms of vascular dementia. In: Kalimo $\mathrm{H}$ (ed) Cerebrovascular diseases. ISN Neuropath Press, Basel, pp 316-323 
49. Jackson C, Sudlow C (2005) Are lacunar strokes really different? A systematic review of differences in risk factor profiles between lacunar and nonlacunar infarcts. Stroke 36:891-901

50. Jellinger K (1977) Cerebrovascular amyloidosis with cerebral hemorrhage. J Neurol 214:195-206

51. Jellinger KA (2002) Alzheimer disease and cerebrovascular pathology: an update. J Neural Transm 109:813-836

52. Jellinger KA (2007) The enigma of vascular cognitive disorder and vascular dementia. Acta Neuropathol 113:349-388

53. Jellinger KA (2008) Morphologic diagnosis of "vascular dementia" - a critical update. J Neurol Sci 270:1-12

54. Jeong JH, Yoon SJ, Kang SJ, Choi KG, Na DL (2002) Hypertensive pontine microhemorrhage. Stroke 33:925-929

55. Joachim CL, Morris JH, Selkoe DJ (1988) Clinically diagnosed Alzheimer's disease: autopsy results in 150 cases. Ann Neurol 24:50-56

56. Johnson MW, Hammond RR, Vinters HV (2005) Fusiform, infectious and other aneurysmal lesions. In: Kalimo $\mathrm{H}$ (ed) Cerebrovascular diseases. ISN Neuropath Press, Basel, pp 112118

57. Jorgensen L, Torvik A (1969) Ischaemic cerebrovascular diseases in an autopsy series. 2. Prevalence, location, pathogenesis, and clinical course of cerebral infarcts. J Neurol Sci 9:285-320

58. Kalaria RN, Erkinjuntti $\mathrm{T}$ (2006) Small vessel disease and subcortical vascular dementia. J Clin Neurol 2:1-11

59. Kawamura J, Meyer JS, Terayama Y, Weathers S (1991) Leukoaraiosis correlates with cerebral hypoperfusion in vascular dementia. Stroke 22:609-614

60. Kida S, Pantazis A, Weller RO (1993) CSF drains directly from the subarachnoid space into nasal lymphatics in the rat. Anatomy, histology and immunological significance. Neuropathol Appl Neurobiol 19:480-488

61. Kimberly WT, Gilson A, Rost NS, Rosand J, Viswanathan A, Smith EE, Greenberg SM (2009) Silent ischemic infarcts are associated with hemorrhage burden in cerebral amyloid angiopathy. Neurology 72:1230-1235

62. Kinnecom C, Lev MH, Wendell L, Smith EE, Rosand J, Frosch MP, Greenberg SM (2007) Course of cerebral amyloid angiopathy-related inflammation. Neurology 68:1411-1416

63. Koennecke HC (2006) Cerebral microbleeds on MRI: prevalence, associations, and potential clinical implications. Neurology 66:165-171

64. Kolovou G, Yiannakouris N, Hatzivassiliou M, Malakos J, Daskalova D, Hatzigeorgiou G, Cariolou MA, Cokkinos DV (2002) Association of apolipoprotein E polymorphism with myocardial infarction in Greek patients with coronary artery disease. Curr Med Res Opin 18:118-124

65. Kölsch H, Larionov S, Dedeck O, Orantes M, Birkenmeier G, Griffin WS, Thal DR (2007) Association of the glutathione $S$-transferase omega-1 Ala140Asp polymorphism with cerebrovascular atherosclerosis and plaque-associated interleukin-1 alpha expression. Stroke 38:2847-2850

66. Kovanen PT (2005) Pathogenesis of carotid atherosclerosis: molecular and genetic aspects. In: Kalimo H (ed) Pathology and genetics: cerebrovascular diseases. ISN Neuropath Press, Basel, pp 74-84

67. Lammie AG (2005) Small vessel disease. In: Kalimo H (ed) Cerebrovascular diseases. ISN Neuropath Press, Basel, pp 85-91

68. Lammie GA (2002) Hypertensive cerebral small vessel disease and stroke. Brain Pathol 12:358-370

69. Lammie GA, Brannan F, Slattery J, Warlow C (1997) Nonhypertensive cerebral small-vessel disease. An autopsy study. Stroke 28:2222-2229

70. Larionov S, Dedeck O, Birkenmeier G, Orantes M, Ghebremedhin E, Thal DR (2006) The intronic deletion polymorphism of the a2-macroglobulin gene modulates the severity and extent of atherosclerosis in the circle of Willis. Neuropathol Appl Neurobiol 32:451-454

71. Larionov S, Dedeck O, Birkenmeier G, Thal DR (2007) Expression of alpha(2)-macroglobulin, neutrophil elastase, and interleukin-1alpha differs in early-stage and late-stage atherosclerotic lesions in the arteries of the circle of Willis. Acta Neuropathol (Berl) 113:33-43

72. Liang J, Liu E, Yu Y, Kitajima S, Koike T, Jin Y, Morimoto M, Hatakeyama K, Asada Y, Watanabe T, Sasaguri Y, Watanabe S, Fan J (2006) Macrophage metalloelastase accelerates the progression of atherosclerosis in transgenic rabbits. Circulation 113:1993-2001

73. Liberato B, Chong JY, Sacco RL (2005) Focal brain ischemia. Clinical features, epidemiology, risk factors and outcome. In: Kalimo H (ed) Cerebrovascular diseases. ISN Neuropath Press, Basel, pp 176-185

74. Lindley RI, Wang JJ, Wong MC, Mitchell P, Liew G, Hand P, Wardlaw J, De Silva DA, Baker M, Rochtchina E, Chen C, Hankey GJ, Chang HM, Fung VS, Gomes L, Wong TY (2009) Retinal microvasculature in acute lacunar stroke: a cross-sectional study. Lancet Neurol 8:628-634

75. Liu S, Ma J, Ridker PM, Breslow JL, Stampfer MJ (2003) A prospective study of the association between APOE genotype and the risk of myocardial infarction among apparently healthy men. Atherosclerosis 166:323-329

76. Lusis AJ, Mar R, Pajukanta P (2004) Genetics of atherosclerosis. Annu Rev Genom Hum Genet 5:189-218

77. Mahley RW (1988) Apolipoprotein E: cholesterol transport protein with expanding role in cell biology. Science 240:622-630

78. Mandybur TI (1979) Cerebral amyloid angiopathy: possible relationship to rheumatoid vasculitis. Neurology 29:1336-1340

79. Mandybur TI (1986) Cerebral amyloid angiopathy: the vascular pathology and complications. J Neuropathol Exp Neurol 45:79-90

80. Markus HS, Hunt B, Palmer K, Enzinger C, Schmidt H, Schmidt R (2005) Markers of endothelial and hemostatic activation and progression of cerebral white matter hyperintensities: longitudinal results of the Austrian Stroke Prevention Study. Stroke 36:1410-1414

81. Marti-Vilalta JL, Arboix A (1999) The Barcelona Stroke Registry. Eur Neurol 41:135-142

82. Masumura M, Hata R, Akatsu H, Kosaka K, Yamamoto T, Nagai Y, Sawada T (2001) Increasing in situ nick end labeling of oligodendrocytes in white matter of patients with Binswanger's disease. J Stroke Cerebrovasc Dis 10:55-62

83. Masumura M, Hata R, Uetsuki T, Nishimura I, Nagai Y, Sawada $\mathrm{T}$ (2001) In vivo gene transfer to cerebral white matter lesions with a recombinant adenovirus vector. Biochem Biophys Res Commun 287:440-444

84. Matsusue E, Sugihara S, Fujii S, Ohama E, Kinoshita T, Ogawa $\mathrm{T}$ (2006) White matter changes in elderly people: MR-pathologic correlations. Magn Reson Med Sci 5:99-104

85. Mazur-Kolecka B, Dickson D, Frackowiak J (2006) Induction of vascular amyloidosis-beta by oxidative stress depends on APOE genotype. Neurobiol Aging 27:804-814

86. Mazur-Kolecka B, Frackowiak J, Carroll RT, Wisniewski HM (1997) Accumulation of Alzheimer amyloid-beta peptide in cultured myocytes is enhanced by serum and reduced by cerebrospinal fluid. J Neuropathol Exp Neurol 56:263-272

87. McCarron MO, Cohen N, Nicoll JAR (2005) Parenchymal brain hemorrhage. In: Kalimo H (ed) Cerebrovascular diseases. ISN Neuropath Press, Basel, pp 294-300

88. McCarron MO, Nicoll JA, Stewart J, Ironside JW, Mann DM, Love S, Graham DI, Dewar D (1999) The apolipoprotein E epsilon2 allele and the pathological features in cerebral amyloid angiopathy-related hemorrhage. J Neuropathol Exp Neurol 58:711-718 
89. Meyer-Luehmann M, Stalder M, Herzig MC, Kaeser SA, Kohler E, Pfeifer M, Boncristiano S, Mathews PM, Mercken M, Abramowski D, Staufenbiel M, Jucker M (2003) Extracellular amyloid formation and associated pathology in neural grafts. Nat Neurosci 6:370-377

90. Mitchell RN, Cotran RS (2003) Hemodynamic disorders, thrombosis, and shock. In: Kumar V, Cotran RS, Robbins SL (eds) Robbins basic pathology. Saunders, Philadelphia

91. Nag S (1996) Immunohistochemical localization of extracellular matrix proteins in cerebral vessels in chronic hypertension. J Neuropathol Exp Neurol 55:381-388

92. Nag S, Robertson DM, Dinsdale HB (1980) Morphological changes in spontaneously hypertensive rats. Acta Neuropathol 52:27-34

93. Namba Y, Tomonaga M, Kawasaki H, Otomo E, Ikeda K (1991) Apolipoprotein E immunoreactivity in cerebral amyloid deposits and neurofibrillary tangles in Alzheimer's disease and kuru plaque amyloid in Creutzfeldt-Jakob disease. Brain Res 541:163-166

94. Neve RL, Finch EA, Dawes LR (1988) Expression of the Alzheimer amyloid precursor gene transcripts in the human brain. Neuron 1:669-677

95. Nicoll JA, Burnett C, Love S, Graham DI, Ironside JW, Vinters HV (1996) High frequency of apolipoprotein E epsilon 2 in patients with cerebral hemorrhage due to cerebral amyloid angiopathy. Ann Neurol 39:682-683

96. O’Brien JT, Erkinjuntti T, Reisberg B, Roman G, Sawada T, Pantoni L, Bowler JV, Ballard C, DeCarli C, Gorelick PB, Rockwood K, Burns A, Gauthier S, DeKosky ST (2003) Vascular cognitive impairment. Lancet Neurol 2:89-98

97. O’Donnell HC, Rosand J, Knudsen KA, Furie KL, Segal AZ, Chiu RI, Ikeda D, Greenberg SM (2000) Apolipoprotein E genotype and the risk of recurrent lobar intracerebral hemorrhage. N Engl J Med 342:240-245

98. O'Sullivan M, Lythgoe DJ, Pereira AC, Summers PE, Jarosz JM, Williams SC, Markus HS (2002) Patterns of cerebral blood flow reduction in patients with ischemic leukoaraiosis. Neurology 59:321-326

99. Okamoto Y, Ihara M, Fujita Y, Ito H, Takahashi R, Tomimoto H (2009) Cortical microinfarcts in Alzheimer's disease and subcortical vascular dementia. Neuroreport 20:990-996

100. Olichney JM, Hansen LA, Hofstetter CR, Lee JH, Katzman R, Thal LJ (2000) Association between severe cerebral amyloid angiopathy and cerebrovascular lesions in Alzheimer disease is not a spurious one attributable to apolipoprotein E4. Arch Neurol 57:869-874

101. Pantoni L, Garcia JH (1997) Pathogenesis of leukoaraiosis: a review. Stroke 28:652-659

102. Petito CK (2005) The neuropathology of focal brain ischemia. In: Kalimo H (ed) Cerebrovascular diseases. ISN Neuropath Press, Basel, pp 215-221

103. Premkumar DR, Cohen DL, Hedera P, Friedland RP, Kalaria RN (1996) Apolipoprotein E-epsilon4 alleles in cerebral amyloid angiopathy and cerebrovascular pathology associated with Alzheimer's disease. Am J Pathol 148:2083-2095

104. Price JL, Davis PB, Morris JC, White DL (1991) The distribution of tangles, plaques and related immunohistochemical markers in healthy aging and Alzheimer's disease. Neurobiol Aging 12:295-312

105. Prins ND, van Dijk EJ, den Heijer T, Vermeer SE, Koudstaal PJ, Oudkerk M, Hofman A, Breteler MM (2004) Cerebral white matter lesions and the risk of dementia. Arch Neurol 61:15311534

106. Rebeck GW, Reiter JS, Strickland DK, Hyman BT (1993) Apolipoprotein E in sporadic Alzheimer's disease: allelic variation and receptor interactions. Neuron 11:575-580
107. Reid AH, Maloney AF (1974) Giant cell arteritis and arteriolitis associated with amyloid angiopathy in an elderly mongol. Acta Neuropathol (Berl) 27:131-137

108. Revesz T, Holton JL, Lashley T, Plant G, Frangione B, Rostagno A, Ghiso J (2009) Genetics and molecular pathogenesis of sporadic and hereditary cerebral amyloid angiopathies. Acta Neuropathol 118:115-130

109. Roher AE, Esh C, Kokjohn TA, Kalback W, Luehrs DC, Seward JD, Sue LI, Beach TG (2003) Circle of Willis atherosclerosis is a risk factor for sporadic Alzheimer's disease. Arterioscler Thromb Vasc Biol 23:2055-2062

110. Roher AE, Lowenson JD, Clarke S, Woods AS, Cotter RJ, Gowing E, Ball MJ (1993) Beta-amyloid-(1-42) is a major component of cerebrovascular amyloid deposits: implications for the pathology of Alzheimer disease. Proc Natl Acad Sci USA 90:10836-10840

111. Roman GC (2002) On the history of lacunes, etat crible, and the white matter lesions of vascular dementia. Cerebrovasc Dis 13(Suppl 2):1-6

112. Roman GC (2004) Brain hypoperfusion: a critical factor in vascular dementia. Neurol Res 26:454-458

113. Rosenberg GA, Kornfeld M, Stovring J, Bicknell JM (1979) Subcortical arteriosclerotic encephalopathy (Binswanger): computerized tomography. Neurology 29:1102-1106

114. Sawada H, Udaka F, Izumi Y, Nishinaka K, Kawakami H, Nakamura S, Kameyama M (2000) Cerebral white matter lesions are not associated with apoE genotype but with age and female sex in Alzheimer's disease. J Neurol Neurosurg Psychiatry 68:653-656

115. Schmechel DE, Saunders AM, Strittmatter WJ, Crain BJ, Hulette CM, Joo SH, Pericak-Vance MA, Goldgaber D, Roses AD (1993) Increased amyloid beta-peptide deposition in cerebral cortex as a consequence of apolipoprotein E genotype in late-onset Alzheimer disease. Proc Natl Acad Sci USA 90:96499653

116. Singh PP, Singh M, Bhatnagar DP, Kaur TP, Gaur SK (2008) Apolipoprotein E polymorphism and its relation to plasma lipids in coronary heart disease. Indian J Med Sci 62:105-112

117. Smith EB (1977) Molecular interactions in human atherosclerotic plaques. Am J Pathol 86:665-674

118. Soontornniyomkij V, Lynch MD, Mermash S, Pomakian J, Badkoobehi H, Clare R, Vinters HV (2009) Cerebral microinfarcts associated with severe cerebral beta-amyloid angiopathy. Brain Pathol 20:459-467

119. Stary HC (2000) Natural history and histological classification of atherosclerotic lesions: an update. Arterioscler Thromb Vasc Biol 20:1177-1178

120. Stary HC, Chandler AB, Dinsmore RE, Fuster V, Glagov S, Insull W Jr, Rosenfeld ME, Schwartz CJ, Wagner WD, Wissler RW (1995) A definition of advanced types of atherosclerotic lesions and a histological classification of atherosclerosis. A report from the Committee on Vascular Lesions of the Council on Arteriosclerosis, American Heart Association. Arterioscler Thromb Vasc Biol 15:1512-1531

121. Stary HC, Chandler AB, Glagov S, Guyton JR, Insull W Jr, Rosenfeld ME, Schaffer SA, Schwartz CJ, Wagner WD, Wissler RW (1994) A definition of initial, fatty streak, and intermediate lesions of atherosclerosis. A report from the Committee on Vascular Lesions of the Council on Arteriosclerosis, American Heart Association. Circulation 89:2462-2478

122. Steen RG, Miles MA, Helton KJ, Strawn S, Wang W, Xiong X, Mulhern RK (2003) Cognitive impairment in children with hemoglobin SS sickle cell disease: relationship to MR imaging findings and hematocrit. Am J Neuroradiol 24:382-389

123. Strittmatter WJ, Weisgraber KH, Huang DY, Dong LM, Salvesen GS, Pericak-Vance M, Schmechel D, Saunders AM, 
Goldgaber D, Roses AD (1993) Binding of human apolipoprotein $\mathrm{E}$ to synthetic amyloid beta peptide: isoform-specific effects and implications for late-onset Alzheimer disease. Proc Natl Acad Sci USA 90:8098-8102

124. Sze G, De Armond SJ, Brant-Zawadzki M, Davis RL, Norman D, Newton TH (1986) Foci of MRI signal (pseudo lesions) anterior to the frontal horns: histologic correlations of a normal finding. Am J Roentgenol 147:331-337

125. Takebayashi S, Kaneko M (1983) Electron microscopic studies of ruptured arteries in hypertensive intracerebral hemorrhage. Stroke 14:28-36

126. Tanskanen M, Lindsberg PJ, Tienari PJ, Polvikoski T, Sulkava R, Verkkoniemi A, Rastas S, Paetau A, Kiuru-Enari S (2005) Cerebral amyloid angiopathy in a 95+ cohort: complement activation and apolipoprotein E (ApoE) genotype. Neuropathol Appl Neurobiol 31:589-599

127. Thal DR (2009) The pre-capillary segment of the blood-brain barrier and its relation to perivascular drainage in Alzheimer's disease and small vessel disease. Sci World J 9:557-563

128. Thal DR, Capetillo-Zarate E, Larionov S, Staufenbiel M, Zurbruegg S, Beckmann N (2009) Capillary cerebral amyloid angiopathy is associated with vessel occlusion and cerebral blood flow disturbances. Neurobiol Aging 30:1936-1948

129. Thal DR, Ghebremedhin E, Orantes M, Wiestler OD (2003) Vascular pathology in Alzheimer's disease: correlation of cerebral amyloid angiopathy and arteriosclerosis/lipohyalinosis with cognitive decline. J Neuropathol Exp Neurol 62:1287-1301

130. Thal DR, Ghebremedhin E, Rüb U, Yamaguchi H, Del Tredici K, Braak H (2002) Two types of sporadic cerebral amyloid angiopathy. J Neuropathol Exp Neurol 61:282-293

131. Thal DR, Griffin WS, Braak H (2008) Parenchymal and vascular Abeta-deposition and its effects on the degeneration of neurons and cognition in Alzheimer's disease. J Cell Mol Med 12:18481862

132. Thal DR, Griffin WST, De Vos RAI, Ghebremedhin E (2008) Cerebral amyloid angiopathy and its relationship to Alzheimer's disease. Acta Neuropathol 115:599-609

133. Thal DR, Larionov S, Abramowski D, Wiederhold KH, Van Dooren T, Yamaguchi H, Haass C, Van Leuven F, Staufenbiel M, Capetillo-Zarate E (2007) Occurrence and co-localization of amyloid beta-protein and apolipoprotein $\mathrm{E}$ in perivascular drainage channels of wild-type and APP-transgenic mice. Neurobiol Aging 28:1221-1230

134. Thal DR, Rüb U, Orantes M, Braak H (2002) Phases of Abetadeposition in the human brain and its relevance for the development of AD. Neurology 58:1791-1800

135. The National Institute on Aging (1997) Consensus recommendations for the postmortem diagnosis of Alzheimer's disease. The National Institute on Aging, and Reagan Institute Working Group on Diagnostic Criteria for the Neuropathological Assessment of Alzheimer's Disease. Neurobiol Aging 18:S1-S2

136. Topakian R, Barrick TR, Howe FA, Markus HS (2010) Bloodbrain barrier permeability is increased in normal appearing white matter in patients with lacunar stroke and leukoaraiosis. J Neurol Neurosurg Psychiatry 81:192-197

137. Ueno M, Tomimoto H, Akiguchi I, Wakita H, Sakamoto H (2002) Blood-brain barrier disruption in white matter lesions in a rat model of chronic cerebral hypoperfusion. J Cereb Blood Flow Metab 22:97-104

138. Urbach H, Tschampa H, Flacke S, Thal DR (2007) MRI of vascular dementia and differential diagnoses or is it really dementia? Clin Neuroradiol 17:88-97

139. Utter S, Tamboli IY, Walter J, Rijal Upadhaya A, Birkenmeier G, Pietrzik CU, Ghebremedhin E, Thal DR (2008) Cerebral small vessel disease-induced apolipoprotein E leakage is associated with Alzheimer disease and the accumulation of amyloid beta-protein in perivascular astrocytes. J Neuropathol Exp Neurol 67:842-856

140. van Swieten JC, van den Hout JH, van Ketel BA, Hijdra A, Wokke JH, van Gijn J (1991) Periventricular lesions in the white matter on magnetic resonance imaging in the elderly. A morphometric correlation with arteriolosclerosis and dilated perivascular spaces. Brain 114(Pt 2):761-774

141. Vinters HV (1992) Cerebral amyloid angiopathy. In: Barnett HJM, Mohr JP, Stein BM, Yatsu FM (eds) Stroke. Pathophysiology, diagnosis and management. Churchill Livingstone, New York, pp 821-858

142. Vinters HV, Ellis WG, Zarow C, Zaias BW, Jagust WJ, Mack WJ, Chui HC (2000) Neuropathologic substrates of ischemic vascular dementia. J Neuropathol Exp Neurol 59:931-945

143. Vinters HV, Gilbert JJ (1983) Cerebral amyloid angiopathy: incidence and complications in the aging brain. II. The distribution of amyloid vascular changes. Stroke 14:924-928

144. Vonsattel JP, Myers RH, Hedley-Whyte ET, Ropper AH, Bird ED, Richardson EP Jr (1991) Cerebral amyloid angiopathy without and with cerebral hemorrhages: a comparative histological study. Ann Neurol 30:637-649

145. Wardlaw JM, Doubal F, Armitage P, Chappell F, Carpenter T, Munoz Maniega S, Farrall A, Sudlow C, Dennis M, Dhillon B (2009) Lacunar stroke is associated with diffuse blood-brain barrier dysfunction. Ann Neurol 65:194-202

146. Weller RO, Djuanda E, Yow HY, Carare RO (2009) Lymphatic drainage of the brain and the pathophysiology of neurological disease. Acta Neuropathol 117:1-14

147. Weller RO, Massey A, Newman TA, Hutchings M, Kuo YM, Roher AE (1998) Cerebral amyloid angiopathy: amyloid beta accumulates in putative interstitial fluid drainage pathways in Alzheimer's disease. Am J Pathol 153:725-733

148. Wilcken DE, Wilcken B (1976) The pathogenesis of coronary artery disease. A possible role for methionine metabolism. J Clin Invest 57:1079-1082

149. Winkler DT, Bondolfi L, Herzig MC, Jann L, Calhoun ME, Wiederhold KH, Tolnay M, Staufenbiel M, Jucker M (2001) Spontaneous hemorrhagic stroke in a mouse model of cerebral amyloid angiopathy. J Neurosci 21:1619-1627

150. Wu CH, Chi JC, Jerng JS, Lin SJ, Jan KM, Wang DL, Chien S (1990) Transendothelial macromolecular transport in the aorta of spontaneously hypertensive rats. Hypertension 16:154-161

151. Yamauchi H, Fukuda H, Oyanagi C (2002) Significance of white matter high intensity lesions as a predictor of stroke from arteriolosclerosis. J Neurol Neurosurg Psychiatry 72:576-582

152. Yamauchi H, Fukuyama H, Nagahama Y, Shiozaki T, Nishizawa S, Konishi J, Shio H, Kimura J (1999) Brain arteriolosclerosis and hemodynamic disturbance may induce leukoaraiosis. Neurology 53:1833-1838

153. Yamori Y, Horie R, Handa H, Sato M, Fukase M (1976) Pathogenetic similarity of strokes in stroke-prone spontaneously hypertensive rats and humans. Stroke 7:46-53

154. Yip AG, McKee AC, Green RC, Wells J, Young H, Cupples LA, Farrer LA (2005) APOE, vascular pathology, and the AD brain. Neurology 65:259-265

155. Zhang ET, Richards HK, Kida S, Weller RO (1992) Directional and compartmentalised drainage of interstitial fluid and cerebrospinal fluid from the rat brain. Acta Neuropathol (Berl) 83:233-239

156. Zhang SH, Reddick RL, Piedrahita JA, Maeda N (1992) Spontaneous hypercholesterolemia and arterial lesions in mice lacking apolipoprotein E. Science 258:468-471

157. Zülch KJ (1961) Über die Entstehung und Lokalisation der Hirninfarkte. Acta Neurol Chir 7:1-117 